\title{
AMAZON TOURISM
}

\author{
Marklea da Cunha Fersta \\ Sara Joana Gadotti dos Anjos ${ }^{b}$
}

\begin{abstract}
AвSTRACT: In this article are presented the topics and approaches developed in this magazine number whose focus is tourism in the amazon. Besides presenting discussion about the topic that aimed at creating this special edition and providing an overview of the content of each article, this editorial article also provides a useful introduction to the potential and challenges of tourism in the Amazon that can be used by researchers as a starting point for your own research. This special edition itself contributes to solving the scarcity of theoretical reflections in this area.
\end{abstract}

\section{Keywords:}

Tourism

Amazon

Potentialities

Challenges 


\section{INTRODUCTION}

The Amazon Forest, also known as Amazon jungle or just Amazon, includes territories of nine nations which $60 \%$ of this is in Brazilian territory followed by Peru where there are $13 \%$. The forest is located also in Ecuador, Venezuela, Bolivia, Guyana, Suriname and French Guiana in smaller percentages which represents more than half of the planet's rainforests. For this reason it is a concern of all states in the world. aiming to promote the harmonious development of the Amazon region and allow an equal distribution of the respective benefits, in 1995 the main region cooperation as an instrument was signed; the Amazon cooperation treaty. Thus, there is a balance between economic growth and environmental conservation, whose responsibility is attached to the dominion of each State. (Desierto e Schnyder von Wartensee, 2021)

In Brazil it occupies 49,29\% of the Brazilian territory and covers three of five regional country's divisions, what they are: North, North East and Midwest. It is considered the biggest country's terrestrial biome.

In order to plan the Amazon region socio economic development in Brazil, was enacted the law $1.806 / 1953$ that created the so-called Legal Amazon (de Souza 2020) that currently corresponds to the area of activity of the Superintendence for the Amazon Development - SUDAM delimited according to the provisions of article Art. $2^{\circ}$ da Complementary law no 124, de 03.01.2007.

Composed for 772 towns, are part of the Legal Amazon 52 Rondônia towns, 22 Acre towns, 62 Amazonas towns, 15 Roraima towns, 144 Pará towns, 16 Amapá towns, 139 Tocantins towns, 141 Mato Grosso towns,as well as, by 181 towns of MaranhãoState located to the west of the $44^{\circ}$, Meridian which 21 of them are partially integrated in the Legal Amazon. having a surface approximately $5.015 .067,75 \mathrm{~km}^{2}$, corresponding to about $58,9 \%$ of Brazilian territory (IBGE 2020).Large in territorial dimensions, yet with a population that corresponds to $12,32 \%$ of the total Brazilian population (SUDAM 2020).

Amazon is one of the 27 federatives units in Brazil. It is located in the North Region, being the largest state in the country in terms of territorial extension, possessing an area of $1559167,878 \mathrm{~km}^{2}$. In August 2021, the state population reached, 4.269 .995 inhabitants, corresponding to $22 \%$ of the population in North region and $2 \%$ of the Brazilian population. The capital Manaus is the largest city in the North region, with 2,1 million inhabitants (IBGE, 2021), having received the award for the best green destination in Latin America, an award granted in a vote made by world tourism market, during the World Travel Market, happened in London in 2009 (AMAZONAS,
2009).

The environment protection, in particular biodiversity, has been one of the major concerns of the national community. In order to minimize environmental impacts, several countries have established so-called protected areas which translate into an effort by humanity to protect the nature and currently occupy $14,9 \%$ of the planet's continental surface and $7,5 \%$ of the ocean area covering $47 \%$ of the significant biodiversity areas (Gazoni e Brasileiro 2021). Thus, when thinking about tourism in Amazon, sustainability has to be a focus of current concern and investments in all aspects.

Having studies in planning and tourism management in Conservation Units (UC) are extremely necessary. In Brazil there has been a high growth of ecotourism in Conservation Units (UC) in recent decades. On the one hand, Ecotourism is positive for the economy. On the other hand, there is the environmental impact of visiting these ecosystems which raises concerns regarding biodiversity and nature degradation. (Rocha et al. 2021).

It is giant in numbers and diversity of cultural and natural attractions allowing us to assess the endless opportunities in terms of investigations to be explored in the tourism field being more specifically in Amazon. Hence the need to carry out environmental impact studies to ensure biodiversity preservation and the environment protection.

\section{OVerview of ARTICles in SPECIAL EDITION}

Considering the complexity of the Amazon state in Brazil, where there are 62 cities distributed in 4 meso regions and 13 micro-regions. It is a state with the greatest territorial extension, but it has the smallest number of population per square kilometer, Ferreira et al present an important reflection on the Conservation Units in the Amazon and propose a discussion on the Parks of the State of Amazon. In addition to presenting a brief reflection related to the Anavilhanas National Park, home to the second largest fluvial archipelago in the world, the Anavilhanas archipelago. The article brings systematized data on the quantity of national, state and town parks and more in-depth considerations about the Anavilhanas National Park and its peculiarities.

As a result, Ferreira et al demonstrate that the parks' natural supply represents a strong ally in the preservation of natural resources and the development of sustainable ecotourism.

Regarding the Anavilhanas Park - a national conservation unit - the authors demonstrate its importance for sustainable ecotourism and the positive results it has generated in this field. 
In order to identify visitor satisfaction in the Tapajós National Forest (FLONA), a Conservation Unit (UC) located in the State of Pará - Brazil, Moreira et al present a methodology for analyzing open comments in research. To carry out the research, the authors collected data at the UC between 2014 and 2016 and discussed the positive and negative points that were pointed out by the visitors they have heard during the research. The article demonstrates the tab of 14,291 data, of which 9,004 are positive comments and 5,287 are negative comments taken from 4,010 forms. The analysis method used was qualitative thematic analysis. The authors classified each comment into 3 categories and 22 subcategories, according to keywords. After analyzing the data, it was identified the visitors' satisfaction to the UC and the generation of data which will contribute to programs for the public use of the park and contribute to the visitation handling.

Going through the historical, socio cultural and tourist elements that make up the famous Avenida Eduardo Ribeiro located in Brazil, in the capital of Amazonas, Magabi, Guimarães and Queroga discuss how the aforementioned Avenue, the historical and tourist aspects that compound it can be analyzed in the context of heritage interpretation. Thus, they present in the article the history of the Avenue and its importance for the formation of the Manaus' cultural heritage; the current elements that make up the landscape of the street, analyzing its relationship with tourism and present a suggestion for a tourist visitation route specifically aimed at Avenida Eduardo Ribeiro take the principles of heritage interpretation as a foundation.

It is important to highlight in the authors' study that Avenida Eduardo Ribeiro is considered the main artery of Downton in Manaus and has important historical buildings along its length. In addition, it is one of the main commercial centers in the capital. Having a historicity that materializes from the centenary buildings that compose it, in its paving and infrastructure, the Avenue becomes an important space for tourist activity in the capital.

By presenting a economic view and entrepreneurial reality in Brazil, Chaves, Anjos and Coutinho present an article that verifies the economic pluralism of Zaoual (2006), identifying different entrepreneurial forms related to community tourism developed in the Bela Vista do Jaraqui community, in the city of Manaus, in Amazon. The authors from a dialectical perspective of qualitative approach conducted a field research in the aforementioned community; aiming to interview and observe the entrepreneurial practices related to community tourism. From the studies concluded, the authors identified entrepreneurial practices that appear as: Bezamat's turnaround entrepreneurship (2017), Zaoual's situated entrepreneurship (2006), and Mandrysz's social entrepreneurship (2020). Finally, the research demonstrates the weaknesses related to com- munity and institutional arrangements.

By presenting the traditional Marujada festival celebrated in Tracuateua city in the Brazilian Amazon, Palheta, Canal and Castro bring an important contribution to the influence of festive events for the sociocultural appreciation of the tourist destination. In order to analyze the festivity and attractiveness of Marujada in the Brazilian Amazon in Tracuateua city, the authors carried out an important survey of documented and bibliographic data, including fieldwork with semi-structured interviews and field notes with guided observation script with 12 organizers and makers of the current party. According to the authors, not only the fraternization among practitioners, but also the attractiveness provided by Marujada contributes to attract tourist flows as well as to encourage the culture of the microregion Bragantina and the strengthening of the festivity, safeguarding the local culture.

A recurrent relevance topic and few scientific approaches is addressed by Santos in the article "The touristic ethnic space and its symbolic interfaces in Manaus-Amazonas-Brazil", which is based on an ethnic perspective as a historical construction of a people's identity. It discusses the touristic ethnic space in an indigenous community located in the metropolitan region of Manaus. Fulfilled in the Sahu-Apé community, the study demonstrates the functional and symbolic dimension within the space formed by a set of unique symbols of the ethnic group, compared to other groups.

Finally, this edition ends by discussing music and cultural identity with an article by Gama and Teixeira who analyze the influence of manauara music on cultural identity through the Tacacá na Bossa event that happens at Largo São Sebastião, an important tourist area in the Amazonian capital in Brazil, where the Teatro Amazonas is located, a prominent tourist attraction in the city. The authors present the historicity of manauara music and the Tacacá na Bossa event and the main characteristics of "manauara music" through local artists and bands. They also discuss the importance of the musical event Tacacá na Bossa for residents as a form of cultural identity.

\section{REFERENCES}

ESTADO DO AMAZONAS, 2009. "Amazonas conquista, em Londres, premio de melhor destino verde da America Latina". $\quad$ http:// www.amazonas.am.gov.br/2009/11/amazonasconquista-em-londres-prêmio-de-melhor-destinoverde-da-amrica-latina/ (22 de setembro de 2021).

Desierto, Diane A., e Ilaria Schnyder von Wartensee. 2021. "The right to development, integral human development, and integral ecology in the Amazon". In- 
ternational Journal of Human Rights 0(0): 1-18. https://doi.org/10.1080/13642987.2020.1853104.

Gazoni, Jefferson Lorencini, e lara Lucia Gomes Brasileiro 2021. "Public visitation and deforestation in protected areas of the Brazilian Amazon: an application of the Linear Probability Model". Journal of Ecotourism $0(0)$ : 1-18. $\quad$ https:// doi.org/10.1080/14724049.2021.1928145.

IBGE. 2020. "IBGE". https://www.ibge.gov.br/geociencias/ organizacao-do-territorio/estrutura-territorial/15819amazonia-legal.html?edicao $=30963 \& \mathrm{t}=0$-que-e $\quad(22$ de setembro de 2021).

Rocha, Cézar Henrique Barra et al. 2021. "Carrying capacity and impact indicators: analysis and suggestions for sustainable tourism in protected areas-Brazil". World Leisure Journal 63(1): 73-97.

de Souza, Caroline Braga Patrocínio. 2020. "Amazônia Ocidental: O que é isso? - Portogente". https:// portogente.com.br/portopedia/112768-amazoniaocidental-o-que-e-isso (22 de setembro de 2021).

SUDAM. 2020. "Legislação da Amazônia - Português (Brasil)". https://www.gov.br/sudam/pt-br/acesso-ainformacoes/institucional/legislacao-da-amazonia (22 de setembro de 2021). 